\title{
Arbuscular Mycorrhizal Fungi (AMF) and Biosolids Enhance the Growth of a Native Australian Grass on Sulphidic Gold Mine Tailings
}

\author{
E. Madejón, A. I. Doronila, J. T. Sanchez-Palacios, P. Madejón, and A. J. M. Bakeı
}

\begin{abstract}
We tested the effect of the addition of biosolids combined with a native mycorrhizal inoculum (Arbuscular Mycorrhizal Fungi [AMF]) on growth of a native Australian grass, and on trace element stabilization of sulphidic gold mine tailings. A glasshouse trial was established on four substrates: tailings ( $T$ ); tailings with a layer of $5 \mathrm{~cm}$ topsoil (TS); tailings amended with $100 \mathrm{dry}$ t ha ${ }^{-1}$ biosolids (LB), and tailings amended with 500 dry $t \mathrm{ha}^{-1}$ biosolids (HB). Pots of $1.2 \mathrm{~L}$ of capacity were established; some were inoculated with a mixture of Glomus sp. (WUM51-9227), Scutelospora aurigloba (WUM51-53), and Acaulospora levis (WUM46) culture mix, and others were uninoculated controls. Seeds of the native Australian grass, Bothriochloa macra were sown in the pots. Root infection, plant biomass production, nutrients and trace element concentrations in shoots were investigated.
\end{abstract}

\section{Introduction}

Mining activities produce large quantities of waste materials such as tailings that frequently contain toxic concentrations of heavy metals and metalloids. Currently, many strategies are used to minimize the production, emission, and dispersion of pollutants from mine sites. Although landscape restoration goals for a given site may be known, the specific strategy to achieve the goals will depend on the type, concentration, and extent of contaminants and the site characteristics.

The use of vegetation cover on unstable degraded land, such as mine spoils and tailings facilities, has been determined to provide an in situ cost-effective and environmentally sustainable method of stabilizing and reclaiming waste lands (Tordoff et al. 2000). The use of vegetation to reduce erosion and provide long-term structural support is known
Addition of biosolids significantly increased AMF infection of roots compared to unamended substrates. No clear qualitative differences in colonization were detected. Addition of biosolids and AMF together clearly improved the establishment and growth of the native grass. Similar trends in nutritional status were shown for biosolids and inoculation with AMF treatments. Mycorrhizal inoculation increased plant biomass production and the effectiveness of nutrient uptake. The combined use of biosolids and mycorrhizal inoculation could be a reliable method for phytostabilization purposes in polluted substrates.

Key words: Acaulospora, biomass production, Glomus, nutritional status, Scutelospora, trace element bioavailability.

as phytostabilization. Revegetation of mine sites is a welldocumented tool for effective surface stabilization, as tailings are usually almost completely devoid of vegetation cover, which increases the likelihood of serious pollution resulting from wind and water erosion of the bare tailings surface (Tordoff et al. 2000; Baker 2002).

Approaches to revegetation may be categorized as ameliorative or adaptive (Tordoff et al. 2000). Both approaches aim to sustain vegetation, though differ in their approach to improving the growth substrate (Johnson et al. 1994). The ameliorative approach to revegetation attempts to achieve optimum conditions for plant growth by improving the physical and chemical nature of derelict land. These conditions can be attained using amendments. Numerous amendments have been employed to immobilize trace elements in contaminated soils (Knox et al. 2001). These include lime, zeolites, apatite, $\mathrm{Fe}$ and $\mathrm{Mn}$ oxides, alkaline composted biosolids, clay minerals, and industrial byproducts such as beringite. The adaptive approach aims to apply ecological principles to facilitate sustainable and long-term phytostabilization. The development of biological processes, especially nutrient cycling, is an integral component of all revegetation schemes which aim to achieve a low-maintenance vegetation cover. This reduces the need for 
repeated fertilizer applications and organic matter amendments (Tordoff et al. 2000).

Mycorrhizal fungi are probably the best known group of soil microorganisms, which influence nutrient uptake patterns of plants (Allen et al. 1992). Endophytic or arbuscular mycorrhizal fungi (AMF) are microscopic fungi that occur naturally in soil and form symbioses with plant roots to produce a mycelium network in soil. Such fungal associations increase the plant contact area with soil and have been shown to enhance root absorption of nutrients and water uptake (Smith et al. 1997). By colonizing the roots, the fungus enhances plant growth by making soil essential elements more accessible (Allen 1991; Treseder \& Allen 2000). Accordingly, mycorrhizal colonization improves vegetation establishment and survival, particularly in adverse edaphic conditions, such as low fertility and arid soils, and increases pathogen resistance (Smith et al. 1997). Mycorrhizal colonization also augments plant resistance toward heavy metal toxicity by limiting metal or metalloid uptake (Weissenhorn et al. 1995), an important factor when using this method for phytostabilization. The presence of mycorrhizae thus has a beneficial role for plants growing in soils which have elevated concentrations of trace metals (Leyval et al. 1997). The absence of AMF can, at the very least, reduce initial establishment of plants on reconstructed landscapes, therefore their presence can increase the success of phytostabilization by improving the growth and survival of establishing vegetation. Enhanced recycling of nutrients in the reconstructed soil profiles will benefit the long-term stability and sustainability of newly created vegetation communities.

In particular, gold mining creates fine sulphidic, saline wastes (tailings), which contain toxic elements and compounds such as cadmium, lead, manganese, cyanide, and particularly arsenic. In some gold mines in Victoria (Australia), As has been detected in concentrations of up to $4,000 \mathrm{mg} \mathrm{kg}^{-1}$, which is 130 times the maximum allowable concentration for a "clean" soil. Little is known about the effects of mycorrhizae on plant establishment in arsenic-rich soils. Several grass species growing on soils with elevated As concentrations have been observed to have this symbiotic association (Dong et al. 2008). However, in a previous study there was no observed improvement in biomass benefit from AMF inoculation (Knudson et al. 2003). Strong evidence that plants with AMF symbioses can develop arsenate resistance has been presented by González-Chávez et al. (2002).

The aim of the work reported here is to combine ameliorative and biological approaches in restoration strategies for arsenic-rich-mine tailings, including amendment with biosolids, establishing native grasses, and inoculation with a mixture of native mycorrhizal fungi. A factorial experiment was designed to test for any possible interactions between mycorrhizal treatment and biosolids application. We hypothesized that the addition of biosolids could improve chemical and physical properties of the tailings, and so enhancing grass productivity. Mycorrhizae were hypothesized to enhance the effectiveness of the biosolids in remediation. We recorded root infection, biomass production, and nutrient and trace element concentrations in shoot dry matter.

\section{Methods}

\section{Experiment Design}

A native Australian $\mathrm{C} 4$ grass species, Bothriochloa macra (Steud.) S.T. Blake (LIG), was selected in consultation with commercial seed supplier, Native Seeds Pty Ltd, on the basis of its drought and salinity tolerance and seed availability. A glasshouse experiment was established to study the effect of biosolids and mycorrhizae on the growth and nutritional status of B. macra grown in tailings. The experiment employed four substrates: tailings (T), tailings and a superficial layer of $5 \mathrm{~cm}$ of top soil (TS), tailings mixed with 100 dry $\mathrm{tha}^{-1}$ of biosolids (LB), and tailing mixed with 500 dry tha ${ }^{-1}$ of biosolids (HB) (Table 1). Tailings were collected from the 15-year-old stockpiles at Stawell Gold Mine, Victoria in October 2007. The topsoil was collected from the surrounding areas of the mine. Biosolids were collected from a stockpile at Melbourne Water's Western Treatment Plant at Werribee, Victoria, Australia.

The substrates were placed in drained pots of $1.2 \mathrm{~L}$ of capacity, with 12 pots per substrate, giving a total of 48 experimental units. Six replicates per treatment (24 in total) were inoculated with a culture of Glomus sp. (WUM51-9227), Scutelospora aurigloba (WUM51-53), and Acaulospora levis (WUM46) supplied by the Department of Soil Science, University of Western Australia. The three AMF species were isolated from lateritic clay topsoil which had been removed prior to bauxite mining in the Darling escarpment near Perth, Western Australia. The cultures were maintained using a Trifolium subterraneum host in a pasteurized 1:1:1 coarse sand, fine sand, and crushed peat moss potting mix. Nutrients were supplied using a low phosphorus slow release fertilizer. Inoculum was prepared by chopping up the roots of the host plants then thoroughly mixing these with proportional amounts of the culture potting mix. Approximately $30 \mathrm{~g}$ (one large spoon) was added on to the surface of each pot with the AMF treatment then grass seeds were sown and covered with a layer of sterilized coarse sand. Seeds of B. macra were sown in the pots and after 20 days all pots were uniformly thinned to five plants/pot. The pots were arranged in a fully randomized experimental design within a glasshouse and rearranged randomly every 2 weeks to minimize the influence of microclimatic variations. All pots were initially watered to maximum water-holding capacity and then by individual drippers every second day for 2 minutes at a flow rate of $2 \mathrm{~L} /$ hour. Additional nitrogen was supplied by adding $44 \mathrm{mg} \mathrm{N}$ as $\mathrm{NH}_{4} \mathrm{NO}_{3}$ per pot every 20 days.

\section{Plant Sampling and Analysis}

Plants were harvested destructively at 90 and 160 days after sowing. The fresh weight of shoots was determined at each harvest. Plant samples were washed for 15 seconds with a $0.1 \mathrm{~N} \mathrm{HCl}$ solution then for 10 seconds with distilled water. Washed samples were oven-dried at $70^{\circ} \mathrm{C}$ and then the dried plant material ground and passed through a $500 \mu \mathrm{m}$ stainless steel sieve prior to analysis. 
Table 1. Means $(n=3)$ and standard deviations (in parenthesis) for the most relevant properties of the materials and the prepared substrates. Pseudo-total elemental analyses obtained from aqua regia digests.

\begin{tabular}{|c|c|c|c|c|c|c|}
\hline & & $T$ & $T S$ & $B$ & $L B$ & $H B$ \\
\hline pH & & $4.2(0.25)$ & $4.12(0.32)$ & - & $4.5(0.07)$ & $4.7(0.12)$ \\
\hline TOC & $\mathrm{g} \mathrm{kg}^{-1}$ & $1.5(0.02)$ & $0.7(0.05)$ & - & $1.8(0.32)$ & $3.1(0.25)$ \\
\hline EC & $\mathrm{mS} \mathrm{cm}^{-1}$ & 3.21 & 2.77 & - & 3.01 & 3.12 \\
\hline $\mathrm{Ca}$ & $\mathrm{mg} \mathrm{kg}^{-1}$ & $20700(2000)$ & $219(8.5)$ & $8357(121)$ & $22094(566)$ & $21044(1202)$ \\
\hline Mg & $\mathrm{mg} \mathrm{kg}^{-1}$ & $9469(59)$ & 379 (6.3) & $2296(110)$ & $10458(99)$ & $10138(28.3)$ \\
\hline $\mathbf{K}$ & $\mathrm{mg} \mathrm{kg}^{-1}$ & $2575(155)$ & $465(47)$ & $4736(236)$ & $4040(35.3)$ & $3830(35.0)$ \\
\hline $\mathbf{N a}$ & $\mathrm{mg} \mathrm{kg}^{-1}$ & $352(12)$ & 137 (14) & $179(6.34)$ & $340(23)$ & $385.5(9.2)$ \\
\hline $\mathbf{S}$ & $\mathrm{mg} \mathrm{kg}^{-1}$ & $22600(700)$ & $420(2.8)$ & $11000(423)$ & $22850(353)$ & $20500(50.0)$ \\
\hline $\mathbf{P}$ & $\mathrm{mg} \mathrm{kg}^{-1}$ & $1632(7.0)$ & 89 (7.6) & 8167 (321) & $1932(50)$ & $2532(49.0)$ \\
\hline As & $\mathrm{mg} \mathrm{kg}^{-1}$ & 2018 (99) & $11.5(1.2)$ & $34.4(2.54)$ & 1840 (14) & 1465 (7.0) \\
\hline Cd & $\mathrm{mg} \mathrm{kg}^{-1}$ & $4.79(0.37)$ & $<0.1$ & $24.7(2.21)$ & $6.30(0.06)$ & $7.74(0.13)$ \\
\hline Co & $\mathrm{mg} \mathrm{kg}^{-1}$ & $23.9(0.39)$ & $2.49(0.33)$ & $13.5(2.40)$ & $31(0.50)$ & $29(0.35)$ \\
\hline $\mathrm{Cr}$ & $\mathrm{mg} \mathrm{kg}^{-1}$ & $52.4(12)$ & $6.20(0.06)$ & $931(88)$ & $77.6(1.13)$ & $188(8.5)$ \\
\hline $\mathrm{Cu}$ & $\mathrm{mg} \mathrm{kg}^{-1}$ & $174(10)$ & $2.77(0.01)$ & $921(48)$ & $233(5.65)$ & $349(6.70)$ \\
\hline Mn & $\mathrm{mg} \mathrm{kg}^{-1}$ & $5359(411)$ & $123(1.1)$ & $94.3(4.00)$ & $6070(56)$ & $6450(28)$ \\
\hline $\mathrm{Ni}$ & $\mathrm{mg} \mathrm{kg}^{-1}$ & $31.5(0.73)$ & $5.31(0.50)$ & $179(16)$ & $49.8(0.63)$ & $61(1.1)$ \\
\hline $\mathbf{P b}$ & $\mathrm{mg} \mathrm{kg}^{-1}$ & 167 (15.6) & $9.60(1.55)$ & $827(54)$ & $202(11)$ & $278(5.65)$ \\
\hline $\mathrm{Zn}$ & $\mathrm{mg} \mathrm{kg}^{-1}$ & $152(25.3)$ & $7.79(2.25)$ & $1309(72)$ & $160(7.8)$ & 314 (12.7) \\
\hline
\end{tabular}

TOC, total organic carbon; EC, electrical conductivity; T, tailings; TS, topsoil; B, biosolids; LB, substrate low biosolids doses; HB, substrate high biosolids doses.

Shoots were digested by wet oxidation with concentrated $\mathrm{HNO}_{3}$ under pressure in a microwave digester. Analysis of nutrients (P, K, Ca, Mg, K, S, and $\mathrm{Na}$ ) and trace elements (As, $\mathrm{Cd}, \mathrm{Cu}, \mathrm{Pb}$, and $\mathrm{Zn}$ ) in the extracts was performed by ICPOES. The $\mathrm{N}$ content was determined by Kjeldahl digestion.

Subsamples of fresh roots were taken and stored in vials. Root fragments were cleared and stained according to the method described by Brundrett (1996). Root samples were washed and then dispensed into McCartney bottles half-filled $(25 \mathrm{~mL})$ with a $10 \% \mathrm{KOH}$ solution. These were autoclaved at $121^{\circ} \mathrm{C}$ for 30 minutes. Samples were poured into a fine mesh strainer and rinsed under tap water.

Cleared roots were soaked in a staining solution for 2 minutes ( $0.05 \%$ trypan blue in a $1: 180 \%$ lactic acid:glycerol solution). Stained root fragments were placed on a slide and then observed under a compound microscope to determine the percentage of mycorrhizal colonization along the length of roots. Thirty root fragments from each sample were measured according to the technique of Giovannetti and Mosse (1990) in which the sample was measured alongside a graticule and the degree of infection estimated along a $1-\mathrm{cm}$ length. Colonization was scored for the presence of arbuscules, vesicles, and internal hyphae.

\section{Substrate Analysis}

Substrate samples from each treatment were taken after the second grass harvest. For chemical analysis soil samples were air-dried, crushed, sieved $(<2 \mathrm{~mm})$, and ground $(<60 \mu \mathrm{m})$. Soil samples for microbiological analysis were sieved $(<2 \mathrm{~mm})$ and stored at $4^{\circ} \mathrm{C}$ prior to analysis.

Dehydrogenase activity was determined in a $1 \mathrm{M}$ Tris$\mathrm{HCl}$ buffer (pH 7.5) by the method of Trevors (1984), using INT (2 (p-iodophenyl)-3-(p-nytrophenyl) 5-phenyl tetrazolium chloride) as the electron acceptor. The iodonitrotetrazolium formazan (INTF) produced was measured spectrophotometrically at $490 \mathrm{~nm}$.

The $\mathrm{pH}$ of the substrates and the biosolids was measured in 1:2.5 sample: $\mathrm{H}_{2} \mathrm{O}$ extracts after shaking for 1 hour. Total heavy metals (HM) and As concentrations in the tailings $(<60 \mu \mathrm{m})$ and in the biosolids were determined by ICPOES (IRIS ADVANTAGE, Thermo Jarrel Ash Corporation, MA, US) after aqua regia digestion in a microwave oven (Microwave Laboratory Station Mileston ETHOS 900, Milestone s.r.l., Sorisole, Italy).

$\mathrm{CaCl}_{2}$-soluble soil trace element concentrations were determined in $1: 10$ substrate sample $(<2 \mathrm{~mm}) \quad 0.01 \mathrm{M} \mathrm{CaCl}_{2}$ extracts (Ure et al. 1993) by ICP-OES.

\section{Statistical Analysis}

Comparison of the different treatment effects by analysis of variance (ANOVA) was performed using the statistical software SPSS 15. Appropriate transformations on the data were made prior to analysis to reduce the heterogeneity of the variance. A correlation matrix between substrate chemical and plant-related parameters was calculated. The significance levels reported $(p<0.01$ and $<0.05)$ are based on Pearson coefficients.

\section{Results}

\section{Biomass Production}

Addition of biosolids and inoculation with AMF improved the growth of the native grass (Fig. 1 and Table 2). This increase was especially noticeable after both AMF and the high rate of biosolids were added. Biomass production in the 


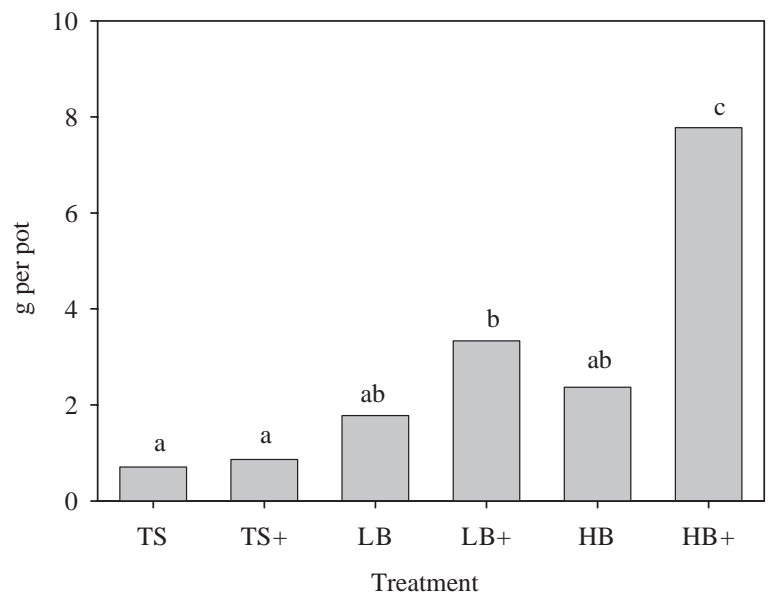

Figure 1. Biomass production (dry weight) in each treatment. (g/pot). Values followed by the same letter above the same bar, do not differ significantly $(p<0.05)$. TS: topsoil LB: substrate low biosolids doses; HB: substrate high biosolids doses.

Table 2. Effect of the two main factors (inoculation with AMF and substrate) and interaction between the two factors presented as $F$-ratios for plant nutrient and trace element contents.

\begin{tabular}{lccc}
\hline & Inoculation & Substrate & Inoculation $\times$ Substrate \\
\hline Biomass (dw) & $\mathbf{1 1 . 2}^{*}$ & $\mathbf{1 7 . 7}^{*}$ & $\mathbf{7 . 3 6}^{*}$ \\
$\mathrm{~N}$ & 2.45 & 0.61 & 0.00 \\
$\mathrm{P}$ & 3.56 & $\mathbf{1 4 . 6}^{*}$ & 0.00 \\
$\mathrm{~S}$ & $\mathbf{5 . 7 7}^{*}$ & $\mathbf{1 0 . 2}^{*}$ & 0.00 \\
$\mathrm{~K}$ & $\mathbf{4 . 5 1}^{*}$ & $\mathbf{5 6 . 3}^{*}$ & 0.01 \\
$\mathrm{Ca}$ & $\mathbf{1 3 . 4}^{*}$ & 2.44 & 0.027 \\
$\mathrm{Mg}$ & 0.08 & $\mathbf{8 . 5 4}^{*}$ & 0.002 \\
$\mathrm{As}$ & $\mathbf{4 . 4 6}^{*}$ & 2.30 & 2.36 \\
$\mathrm{Cd}$ & $\mathbf{1 7 . 0}^{*}$ & $\mathbf{3 7 . 5}^{*}$ & 0.75 \\
$\mathrm{Cu}$ & 0.22 & $\mathbf{6 . 3 5}^{*}$ & 2.68 \\
$\mathrm{Ni}$ & 0.75 & $\mathbf{7 . 4 2}^{*}$ & 1.66 \\
$\mathrm{~Pb}$ & 0.38 & $\mathbf{3 . 4 7}^{*}$ & 3.12 \\
$\mathrm{Zn}$ & 0.09 & $\mathbf{2 1 . 3}^{*}$ & 0.26 \\
\hline
\end{tabular}

*Indicates statistical significance.

treatment without any amendment $(\mathrm{T})$ was very low and in some pots no grass survival was recorded. Values for this treatment were therefore excluded from the statistical analysis. For the remaining treatments, biomass production (dry weight) obtained by the sum of both harvests varied from 0.51 to $8.44 \mathrm{~g} \mathrm{pot}^{-1}$ (Fig. 1) and decreased in the order $\mathrm{HB}+>$ $\mathrm{LB}+>\mathrm{HB}>\mathrm{LB}>\mathrm{TS}+>\mathrm{TS}$. It was increased by $5-$ to $10-$ folds in treatments $\mathrm{HB}$ and LB compared to TS. Inoculation with AMF also improved the growth of the native grass as shown by the differences in yield between each substrate with and without inoculation. For biomass production, there was a positive interaction between inoculation with AMF and addition of substrate (Table 2).

\section{Root Mycorrhizal Colonization}

Mycorrhizal colonization was similar in all amended inoculated treatments which ranged from $27 \%$ to $31 \%$. These
Table 3. Percentage of mycorrhizal colonization of roots.

\begin{tabular}{lcr}
\hline Treatment & $\begin{array}{c}(-M C) \\
\text { \% Infection }\end{array}$ & $\begin{array}{c}(+M C) \\
\text { Infection }\end{array}$ \\
\hline T & $<1 \mathrm{a}$ & $9.1 \mathrm{a}$ \\
TS & $6.82 \mathrm{c}$ & $30.1 \mathrm{~b}$ \\
LB & $2.47 \mathrm{~b}$ & $28.5 \mathrm{~b}$ \\
HB & $3.47 \mathrm{~b}$ & $27.0 \mathrm{~b}$ \\
\hline
\end{tabular}

T, tailings; TS, topsoil; LB, substrate low biosolids doses; HB, substrate high biosolids doses. Values followed by the same letter in the same column do not differ significantly $(p<0.05)$.

values were statistically higher than tailings inoculated but without amendment addition (Table 3). Low levels of colonization $(2.5-6.8 \%)$ were also detected in the uninoculated treatments.

\section{Plant Nutrient Concentration}

Due to similarity of macronutrient and trace elements concentrations in shoots of at the two harvests, only data from the first harvest are presented here (Figs. 2 and 3). In the case of the $\mathrm{T}$ treatment, as previously mentioned, the quantity of plant material was not sufficient to perform chemical analysis. In general, mean concentrations of macronutrients $(\mathrm{Ca}, \mathrm{Mg}$, $\mathrm{K}$, and $\mathrm{P}$ ) were higher in the plants growing in soils amended with biosolids (LB and HB) in both inoculated and uninoculated treatments than in plants grown in the topsoil treatment (TS) (Fig. 2). In the case of S, the highest values were found in TS treatments. Because of the equal mineral nitrogen fertilization in all pots, $\mathrm{N}$ concentrations in plants were similar for all treatments. There was no consistent effect of inoculation with AMF on plant nutrient concentrations. Concentrations of nutrients were in the normal range for grasses (Madejón et al. 2002). Interaction between the two main factors inoculation with AMF and substrates was not significant for any plant nutrient (Table 2).

However, the main benefit from the combined addition of biosolids and AMF is the increased total uptake of all macronutrients (Table 4). Values of total macronutrient uptake clearly demonstrated the effect of both AMF and biosolids on grasses.

Table 4. Nutrient uptake by grass growing in the different treatments.

$$
N
$$

\begin{tabular}{lcccccc} 
Treatmentmg per pot & $P$ & $K$ & $C a$ & $M g$ & $S$ \\
\hline TS & $14.9 \mathrm{a}$ & $0.72 \mathrm{a}$ & $9.04 \mathrm{a}$ & $2.75 \mathrm{a}$ & $0.79 \mathrm{a}$ & $3.49 \mathrm{a}$ \\
TS+ & $16.5 \mathrm{a}$ & $1.00 \mathrm{a}$ & $8.53 \mathrm{a}$ & $3.41 \mathrm{a}$ & $1.00 \mathrm{a}$ & $3.45 \mathrm{a}$ \\
LB & $44.2 \mathrm{ab}$ & $2.05 \mathrm{ab}$ & $38.6 \mathrm{ab}$ & $8.36 \mathrm{ab}$ & $2.48 \mathrm{a}$ & $7.14 \mathrm{ab}$ \\
LB+ & $66.8 \mathrm{~b}$ & $4.97 \mathrm{~b}$ & $78.6 \mathrm{~b}$ & $14.5 \mathrm{~b}$ & $4.58 \mathrm{~b}$ & $13.3 \mathrm{~b}$ \\
HB & $58.1 \mathrm{~b}$ & $4.15 \mathrm{~b}$ & $61.1 \mathrm{~b}$ & $15.6 \mathrm{~b}$ & $4.10 \mathrm{ab}$ & $8.94 \mathrm{ab}$ \\
HB + & $147 \mathrm{c}$ & $15.2 \mathrm{c}$ & $172 \mathrm{c}$ & $30.9 \mathrm{c}$ & $16.2 \mathrm{c}$ & $23.0 \mathrm{c}$ \\
\hline
\end{tabular}

TS, topsoil; LB, substrate low biosolids doses; HB, substrate high biosolids doses. Values followed by the same letter in the same column do not differ significantly $(p<0.05)$. 

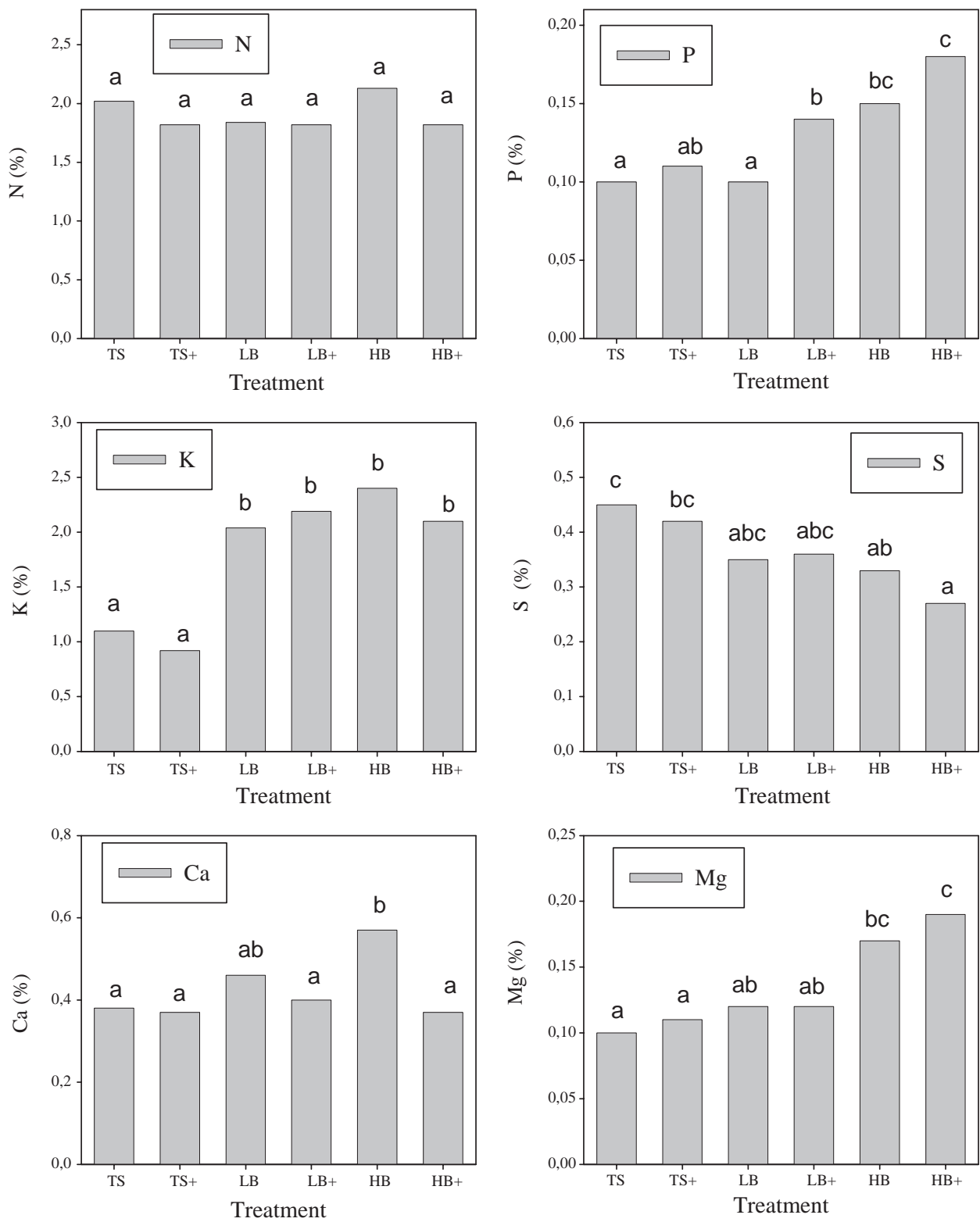

Figure 2. Nutrient concentrations in shoot dry matter (first harvest). Values followed by the same letter above the same bar do not differ significantly $(p<0.05)$. TS: topsoil; LB: substrate low biosolids doses; HB: substrate high biosolids doses.

\section{Trace Element Concentration}

Arsenic concentrations were very low $\left(0.70-1.33 \mathrm{mg} \mathrm{kg}^{-1}\right)$ in plants grown in all treatments, and no differences between treatments were found (Fig. 3). Mean concentrations of $\mathrm{Cd}$ varied between 0.10 and $0.74 \mathrm{mg} \mathrm{kg}^{-1}$. Cd concentrations were higher in biosolid (LB and $\mathrm{HB}$ ) treatments. Inoculation with AMF reduced As and Cd concentrations in shoots (Fig. 3 and Table 2). Mean concentrations of $\mathrm{Cu}$ varied only between 9.0 and $13.8 \mathrm{mg} \mathrm{kg}^{-1}$ (Fig. 3) and were very similar in all treatments. Nickel concentrations varied between 12.7 and $33.4 \mathrm{mg} \mathrm{kg}^{-1}$ and were lower in $\mathrm{HB}+$ treatment. Mean values of $\mathrm{Pb}$ were also very similar in all treatments and only ranged between 1.27 and $2.58 \mathrm{mg} \mathrm{kg}^{-1}$. As with $\mathrm{Cd}$, $\mathrm{Zn}$ concentrations were higher $\left(42.4-94.0 \mathrm{mg} \mathrm{kg}^{-1}\right)$ in plants in the biosolid treatments (Fig. 3). Inoculation with AMF did not affect plant $\mathrm{Cu}, \mathrm{Pb}, \mathrm{Ni}$, and $\mathrm{Zn}$ concentrations. There was no evidence of interaction between inoculation and substrates for any of the trace elements determined (Table 2). As a rule, total uptake of all trace elements (Table 5) was higher in $\mathrm{HB}+$ treatment.

\section{Substrate Analysis}

The addition of biosolids increased the $\mathrm{pH}$ of the tailings, whereas EC values were not affected (Table 6). Inoculation 

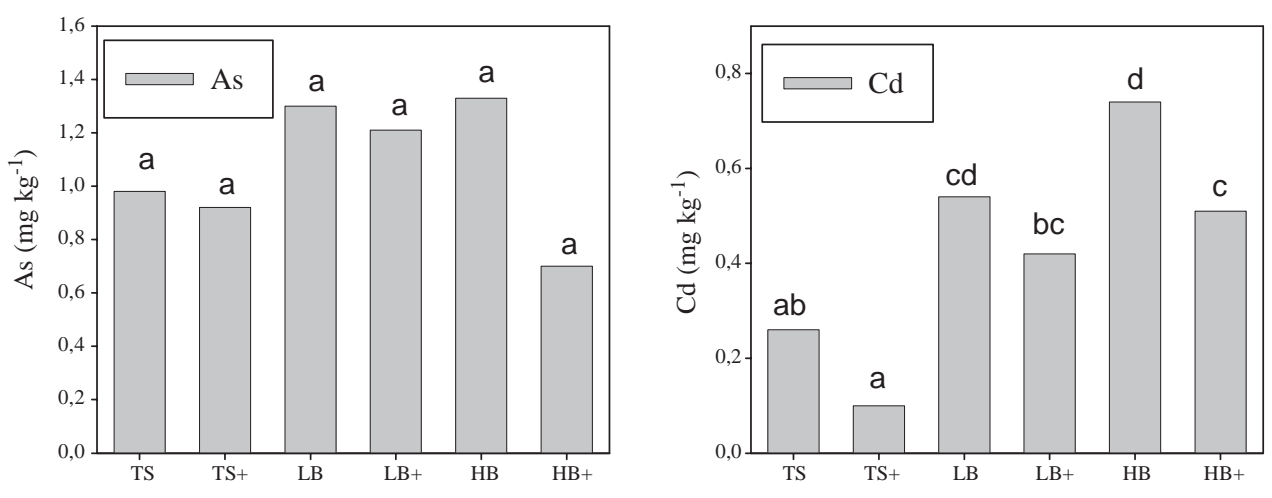

Treatment

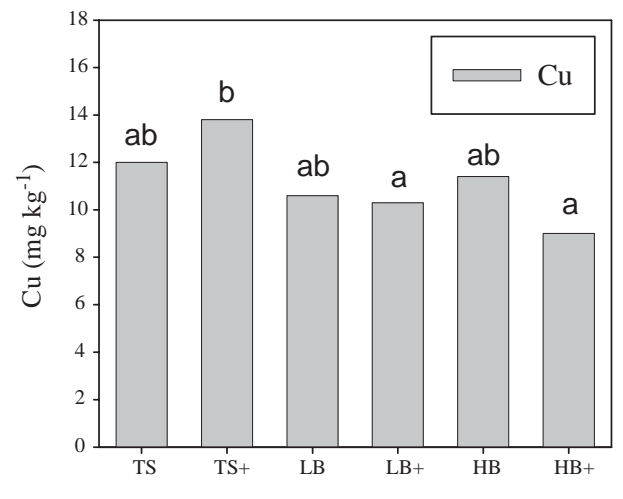

Treatment

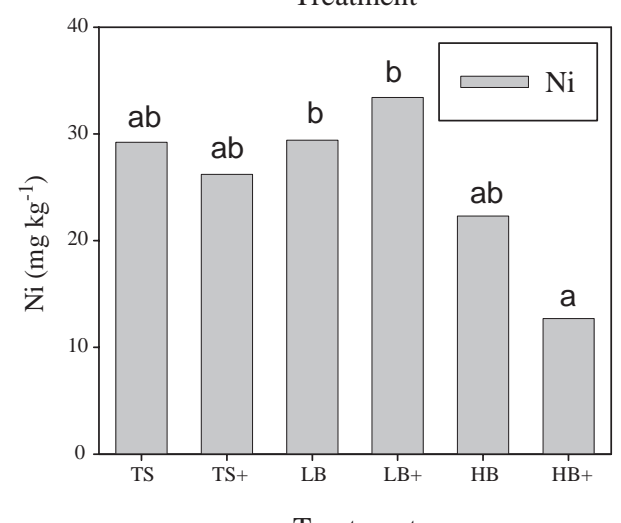

Treatment

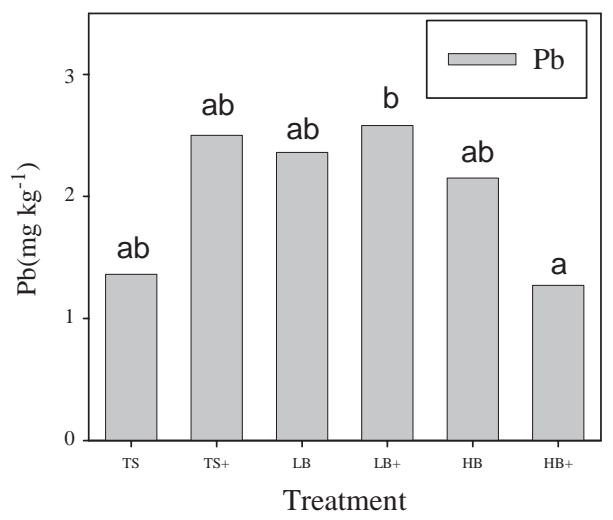

Treatment

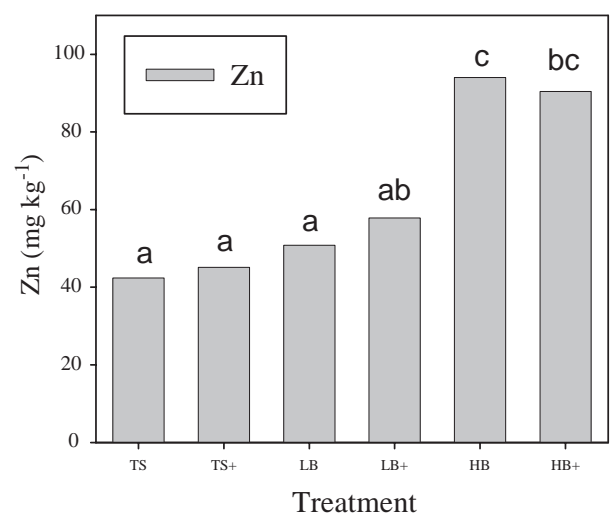

Figure 3. Trace element concentrations in shoot dry matter (first harvest). Values followed by the same letter above the same bar do not differ significantly $(p<0.05)$. TS: topsoil; LB: substrate low biosolids doses; HB: substrate high biosolids doses.

Table 5. Trace element uptake by grass growing in the different treatments.

\begin{tabular}{|c|c|c|c|c|c|c|}
\hline Treatment & As & $C d$ & $\mathrm{Cu}$ & $N i$ & $P b$ & $Z n$ \\
\hline \multicolumn{7}{|c|}{$\mu \mathrm{g}$ per pot } \\
\hline TS & $0.82 \mathrm{a}$ & $0.20 \mathrm{a}$ & $8.69 \mathrm{a}$ & $23.3 \mathrm{a}$ & $0.84 \mathrm{a}$ & $31.7 \mathrm{a}$ \\
\hline $\mathbf{T S}+$ & $0.93 \mathrm{a}$ & $0.09 \mathrm{a}$ & $12.9 \mathrm{a}$ & $24.0 \mathrm{a}$ & $2.35 \mathrm{a}$ & $43.0 \mathrm{a}$ \\
\hline LB & $2.35 \mathrm{ab}$ & $0.95 \mathrm{ab}$ & $19.5 \mathrm{ab}$ & $62.0 \mathrm{ab}$ & $3.89 \mathrm{a}$ & $90.8 \mathrm{ab}$ \\
\hline $\mathbf{L B}+$ & $4.16 \mathrm{bc}$ & $1.49 \mathrm{ab}$ & $37.1 \mathrm{~b}$ & $110 \mathrm{~b}$ & $8.74 \mathrm{bc}$ & $208 \mathrm{~b}$ \\
\hline HB & $3.74 \mathrm{bc}$ & $2.00 \mathrm{~b}$ & $28.7 \mathrm{ab}$ & $50.7 \mathrm{a}$ & $4.94 \mathrm{ab}$ & $229 \mathrm{~b}$ \\
\hline $\mathbf{H B}+$ & $5.24 \mathrm{c}$ & $4.05 \mathrm{c}$ & $73.8 \mathrm{c}$ & $105 \mathrm{~b}$ & $11.0 \mathrm{c}$ & $688 \mathrm{c}$ \\
\hline
\end{tabular}


Table 6. Mean values of the most relevant properties of the substrates at the end of the experiment. $+/-$ refer to mycorrhizal inoculation.

\begin{tabular}{|c|c|c|c|c|c|c|c|}
\hline Treatment & $p H$ & $\begin{array}{c}E C \\
\left(\mathrm{mS} \mathrm{cm}^{-1}\right)\end{array}$ & $\begin{array}{c}\text { Dehydrogenase } \\
\left(m g \mathrm{~kg}^{-1} I N T F h^{-1}\right)\end{array}$ & $\begin{array}{c}C d \\
m g k g^{-1}\end{array}$ & $\mathrm{Cu}$ & $N i$ & $Z n$ \\
\hline $\mathrm{T}$ & $2.97 \mathrm{a}$ & $3.02 \mathrm{bc}$ & $0.27 \mathrm{a}$ & $0.10 \mathrm{ab}$ & $7.42 \mathrm{a}$ & $9.95 \mathrm{a}$ & $17.3 \mathrm{a}$ \\
\hline $\mathrm{T}+$ & $2.81 \mathrm{a}$ & $3.21 \mathrm{c}$ & $0.49 \mathrm{ab}$ & $0.04 \mathrm{ab}$ & $7.15 \mathrm{a}$ & $4.19 \mathrm{a}$ & $10.1 \mathrm{a}$ \\
\hline $\mathrm{TS}$ & $2.99 \mathrm{a}$ & $2.49 \mathrm{ab}$ & $0.44 \mathrm{ab}$ & $0.00 \mathrm{a}$ & $1.84 \mathrm{a}$ & $0.95 \mathrm{a}$ & $6.70 \mathrm{a}$ \\
\hline TS+ & $2.81 \mathrm{a}$ & $2.45 \mathrm{a}$ & $0.69 \mathrm{~b}$ & $0.02 \mathrm{a}$ & $3.38 \mathrm{a}$ & $1.77 \mathrm{a}$ & $7.70 \mathrm{a}$ \\
\hline LB & $4.08 \mathrm{~b}$ & $2.40 \mathrm{a}$ & $1.15 \mathrm{c}$ & $0.24 \mathrm{abc}$ & $2.49 \mathrm{a}$ & $2.75 \mathrm{a}$ & $11.0 \mathrm{a}$ \\
\hline $\mathrm{LB}+$ & $4.17 \mathrm{~b}$ & $2.53 \mathrm{ab}$ & $1.56 \mathrm{~d}$ & $0.16 \mathrm{abc}$ & $1.55 \mathrm{a}$ & $3.22 \mathrm{a}$ & $8.00 \mathrm{a}$ \\
\hline $\mathrm{HB}$ & $4.94 \mathrm{c}$ & $2.58 \mathrm{ab}$ & $1.46 \mathrm{~cd}$ & $0.37 \mathrm{c}$ & $1.31 \mathrm{a}$ & $5.31 \mathrm{a}$ & $18.4 \mathrm{a}$ \\
\hline $\mathrm{HB}+$ & $4.57 \mathrm{bc}$ & $2.66 \mathrm{ab}$ & $1.53 \mathrm{~d}$ & $0.25 \mathrm{bc}$ & $0.40 \mathrm{a}$ & $3.34 \mathrm{a}$ & $11.0 \mathrm{a}$ \\
\hline
\end{tabular}

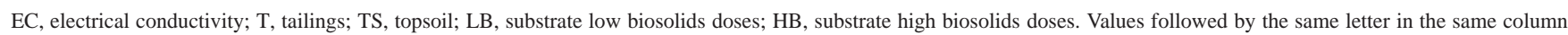
do not differ significantly $(p<0.05)$.

Table 7. Effect of the two main factors (inoculation with AMF and substrate) and interaction between the two factors presented as $F$-ratios for some parameters of the substrates.

\begin{tabular}{lccc}
\hline & Inoculation & Substrate & Inoculation $\times$ Substrate \\
\hline pH & 0.32 & $\mathbf{2 2 . 3}^{*}$ & 0.83 \\
EC & 3.70 & $\mathbf{1 0 . 7}^{*}$ & 0.88 \\
Dehydrogenase & 4.00 & $\mathbf{4 8 . 6}^{*}$ & 1.58 \\
$\mathrm{CaCl}_{2}-\mathrm{Cd}$ & 2.59 & $\mathbf{1 4 . 0}^{*}$ & 0.55 \\
$\mathrm{CaCl}_{2}-\mathrm{Cu}$ & 0.01 & $\mathbf{4 . 3 5}^{*}$ & 0.19 \\
$\mathrm{CaCl}_{2}-\mathrm{Ni}$ & 2.63 & $\mathbf{5 . 9 4}^{*}$ & 2.34 \\
$\mathrm{CaCl}_{2}-\mathrm{Zn}$ & 1.94 & 1.41 & 0.45 \\
\hline
\end{tabular}

*Indicates statistical significance.

with AMF did not affect $\mathrm{pH}$ or EC values in the substrates. Dehydrogenase activity was higher in soil amended with biosolids. In general, dehydrogenase activity was higher for inoculated soils, although differences were not significant (Table 6).

$\mathrm{CaCl}_{2}$-soluble trace element concentrations were generally similar for all substrates (Table 4). $\mathrm{CaCl}_{2}$-soluble concentrations of $\mathrm{As}$ and $\mathrm{Pb}$ in all substrates were below the detection limits $\left(<0.1 \mathrm{mg} \mathrm{kg}^{-1}\right)$. The concentration of $\mathrm{Cd}$ was higher in the HB treatment than in the T and TS treatments. Inoculation with AMF did not have any clear influence on trace element solubility.

Interaction between the two main factors, inoculation with AMF and substrates was not significant for any variable (Table 7).

\section{Discussion}

The inoculum used in our experiment was a mixture of laboratory strains of endophytes which did not appear to be inhibited by growing their host in the arsenic-rich sulphidic tailings or by the presence of heavy metals in the biosolids used. Mycorrhizal colonization rates in roots produced in tailings were similar to those reported for field isolates of Glomus mosseae (28\%) from Holcus lanatus roots (GonzálezChávez et al. 2002). Other studies showed that mycorrhizae isolated from As mine spoils had similar colonization rates but did not enhance growth of basin wildrye, Leymus cinereus (Knudson et al. 2003). This highlights the need for screening of AMF isolates in order to determine the tolerance and the efficacy of field-collected strains in relation to the specific edaphic conditions of mine wastes.

Addition of biosolids increases the plant biomass and the shoot concentrations of several plant nutrients. Use of amendments and introduction of metal-tolerant plants has been proposed as a cost-effective approach to remediation of metalcontaminated soils, which most closely follow natural processes (Gunn et al. 1995). Inoculation with AMF increases the effectiveness of nutrient uptake and plant biomass production. These effects are especially important in degraded or/and contaminated soils. In this case, our findings are also consistent with the extensively documented enhanced growth effects of plants which have the symbiotic association (Smith et al. 1997). However, mycorrhizal proliferation has been reported to decline in the presence of elevated soil phosphorus concentrations (Hetrick et al. 1994). Most biosolids contain elevated levels of phosphorus therefore it is likely that these would inhibit root colonization by the fungal symbionts. This was not the case here, possibly due to the phosphorus being strongly bound to the humic substances in the biosolids. The AMF are then able to mediate the solubilization and uptake of this nutrient.

The results showed a greater uptake of $\mathrm{N}, \mathrm{P}, \mathrm{K}, \mathrm{Ca}$, and $\mathrm{Mg}$ in soils treated with biosolids and especially in the inoculated treatments. This could have very important implications for the long-term sustainability of an ecosystem. The increase of $\mathrm{S}$ concentration found in soils treated with top soil could be due to a concentration effect for the lower biomass recorded for these treatments.

Arsenic concentrations were generally within normal levels for plants (0.01-1 $\mathrm{mg} \mathrm{kg}^{-1}$ ) (Chaney 1989). Similar concentrations were reported by Madejón et al. (2002) in Cynodon dactylon and Sorghum halepense growing on contaminated soils. Despite the high concentrations of As in the substrate, plants did not show high levels of these elements in their tissues. This can be related to rapid change of As from soluble into precipitated forms and to preferential As accumulation in roots or tuber tissues (Smith et al. 1998). Cadmium and Zn concentrations were also within normal levels for plants 
(Chaney 1989). However, in the case of Cd the limit for livestock (0.5 mg kg-1; Chaney 1989) was slightly exceeded in $\mathrm{HB}$ and $\mathrm{LB}$ treatments. Cadmium and $\mathrm{Zn}$ have a high soil-plant transfer coefficient and may pose higher risks than other elements for grazing species. Inoculation with AMF did reduce $\mathrm{Cd}$ uptake. This fact could be related to the precipitation processes that take place in roots that reduce the transfer of this element to the aerial parts (Joner et al. 2000). This was not the case with $\mathrm{Zn}$. The concentrations of $\mathrm{Ni}, \mathrm{Pb}$, and $\mathrm{Cu}$ tended to be lower in the treatment with highest biomass, implying dilution due to better plant growth. Concentrations of $\mathrm{Cu}, \mathrm{Ni}$, and $\mathrm{Pb}$ were in the normal range for grasses and inoculation with AMF did not affect shoot contents of these metals.

Trace element concentrations in plants of the biosolidamended pots were in general higher than those of plants from TS, and the total amount of trace elements uptake in the LB and HB was much higher. Trace elements removed by the plant may potentially enter a new biogeochemical cycle. When plants decompose and trace elements are returned to the soil, they may occupy different parts of the total soil pool to those not removed. However, this fact is unavoidable if the revegetation of the area is the final goal in order to create a remediation strategy. It is therefore important to reduce the uptake of toxic elements by plants, which can be done successfully by adjusting amendment addition and the use of inoculation with AMF, and then to monitor trace element contents of different plant species growing in the affected area.

The results from this experiment show that the addition of biosolids enhanced the growth of the grass in arsenicrich tailings. Increased biomass correlated with biosolids addition and inoculation with AMF. Enhanced plant biomass production was measured in the $\mathrm{LB}$ and $\mathrm{HB}$ treatments, and especially so in HB. This could be attributed to $\mathrm{pH}$ changes and to the improvement of tailings conditions (improvement of physical properties and nutrient addition). The positive correlation between substrate $\mathrm{pH}$ and plant biomass production confirms this suggestion. In this manner, improvement of soil conditions can enhance the process of vegetation development.

The low values of dehydrogenase activity observed in all substrates display the poor microbiological status of the original tailings. The addition of biosolids and the inoculation with AMF increased the biological activity of the substrates. The influence of organic amendments on enzyme activities in contaminated soils has been the subject of several recent studies (Pérez de Mora et al. 2006). In the present study, we did not find any clear relationship between trace element concentrations and dehydrogenase activity. Activity of this enzyme was positively correlated with soil $\mathrm{pH}$ indicating the beneficial effect of the amendments on soil $\mathrm{pH}$. Ellis et al. (2003) found that $\mathrm{pH}$ had the greatest influence on dehydrogenase activity in a $\mathrm{Zn}$-polluted soil. Inoculation with AMF increases the activity of this soil enzyme indicating an improvement of the organic matter turnover. An increase in enzymatic activities in the rhizosphere of inoculated plants has been observed previously (Vivas et al. 2005). These authors attributed this increase to the effect of nutrient leakage from roots. The effectiveness of AMF could also be the result of an indirect effect through changes in microbial composition of the rhizosphere (Medina et al. 2006). In this study we did not quantify root biomass but this measure is usually strongly correlated with shoot biomass. In any case, we found a good correlation between values of dehydrogenase activity and shoot biomass.

\section{Conclusions}

Amending sulphidic and arsenical mine tailings with metal contaminated biosolids and AMF inoculation increased the development of a native grass by improving nutrient uptake. The improvement of the physical, chemical, and biological conditions of the otherwise toxic tailings through the biosolids addition enhanced plant survival and development. Moreover, inoculation with AMF can clearly enhance the effectiveness of the biosolids application in phytostabilization of tailings. Despite the elevated phosphorus levels in the biosolids which can suppress AMF proliferation, our findings further support the positive benefit of inoculating wastes with soil microflora essential for the nutrient cycling processes and as well as inhibiting uptake of toxic trace elements which then enables these remade mine soils to support stable and self-sustaining plant communities. Although further field experiments are necessary, the combination of arbuscular mycorrhizal fungi (AMF) and biosolids proves to be a promising technique for restoration of arsenical mine tailings.

\section{Implications for Practice}

- Creating a mine soil on non-acidic arsenic-rich sulphidic tailings is possible with biosolids amendments.

- An Australian native grass species Bothriocloa macra showed improved establishment on biosolids amended tailings with a multispecies fungal inoculum.

- AMF inoculation reduced uptake of heavy metals and arsenic from metal contaminated biosolids and tailings and thus diminishing the risk for the food chain.

\section{Acknowledgments}

Dr. E. Madejón received financial support for her work at The University of Melbourne (Australia) from Program Salvador de Madariaga of the Spanish MEC. This support is acknowledged with thanks.

\section{LITERATURE CITED}

Allen, M. F. 1991. The ecology of mycorrhizae. Cambridge University Press, Cambridge.

Allen, M. F., S. D. Clouse, B. S. Weinbaum, S. Jeakins, C. F. Friese, and E. B. Allen. 1992. Mycorrhizae and the integration of scales: from molecules to ecosystems. Pages 488-516 in M. F. Allen, editor. Mycorrhizal functioning: an integrative plant-fungal process. Chapman and Hall, New York. 
Baker, A. J. M. 2002. The use of tolerant plants and hyperaccumulators. Pages 138-148 in M. H. Wong and A. D. Bradshaw, editors. The restoration and management of derelict land; modern approaches. World Scientific Publishing Co., Singapore.

Brundrett, M., Australian Centre for International Agricultural Research. 1996. Working with mycorrhizas in forestry and agriculture. Australian Centre for International Agricultural Research, Canberra.

Chaney, R. L. 1989. Toxic element accumulation in soils and crops: protecting soil fertility and agricultural food-chains. Pages $140-158$ in B. BarYosef, N. J. Barrow, and J. Goldshmid, editors. Inorganic contaminants in the vadose zone. Springer-Verlag, Berlin.

Dong, Y., Y. Zhu, F. A. Smith, Y. Wang, and Y. Chen. 2008. Arbuscular mycorrhiza enhanced arsenic resistance of both white clover (Trifolium repens Linn.) and ryegrass (Lolium perenne L.) plants in an arseniccontaminated soil. Environmental Pollution 155:174-181.

Ellis, R. J., P. Morgan, A. J. Weightman, and J. C. Fry. 2003. Cultivationdependant and -independant approaches for determining bacterial diversity in heavy-metal contaminated soil. Applied and Environmental Microbiology 69:3223-3230.

Giovannetti, M., and B. Mosse. 1990. An evaluation of techniques for measuring vesicular arbuscular mycorrhizal infection in roots. New Phytologist 84:489-500.

González-Chávez, C., P. J. Harris, J. Dodd, and A. A. Meharg. 2002. Arbuscular mycorrhizal fungi confer enhanced arsenate resistance on Holcus lanatus. New Phytologist 155:163-171.

Gunn, J., W. Keller, J. Negusanti, R. Potvin, P. Beckett, and K. Winterhalder. 1995. Ecosystem recovery after emission reductions: Sudbury, Canada. Water Air and Soil Pollution 85:1783-1788.

Hetrick, B. A. D., G. W. T. Wilson, and D. A. H. Figge. 1994. The Influence of mycorrhizal symbiosis and fertilizer amendments on establishment of vegetation in heavy-metal mine spoil. Environmental Pollution 86: $171-179$.

Johnson, M. S., J. A. Cooke, and J. K. W. Stevenson. 1994. Revegetation of metalliferous wastes and land after metal mining. Pages 31-47 in R. E. Hester, and R. M. Harrison, editors. Mining and its environmental impact. Royal Society of Chemistry Publishing, Cambridge.

Joner, E. J., R. Briones, and C. Leyval. 2000. Metal-binding capacity of arbuscular mycorrhizal mycelium. Plant and Soil 226:227-234.

Knox, A., J. C. Seaman, M. J. Mench, and J. Vangronsveld. 2001. Remediation of metal- and radionuclides-contaminated soils by in situ stabilization techniques. Pages 21-60 in I. K. Iskandar, editor. Environmental restoration of metal-contaminated soils. Lewis Publishers, Boca Raton, Florida.
Knudson, J. A., T. Meikle, and T. H. DeLuca. 2003. Role of mycorrhizal fungi and phosphorus in the arsenic tolerance of basin wildrye. Journal of Environmental Quality 32:2001-2006.

Leyval, C., K. Turnau, and K. Haselwandter. 1997. Effect of heavy metal pollution on Mycorrhizal colonization and function: physiological, ecological and applied aspects. Mycorrhiza 7:139-153.

Madejón, P., J. M. Murillo, T. Marañón, F. Cabrera, and R. López. 2002. Bioaccumulation of $\mathrm{As}, \mathrm{Cd}, \mathrm{Cu}, \mathrm{Fe}$ and $\mathrm{Pb}$ in wild grasses affected by the Aznalcóllar mine spill (SW Spain). Science of the Total Environment 290: $105-120$.

Medina, A., M. Vassileva, J. M. Barea, and R. Azcón. 2006. The growthenhancement of clover by Aspergillus-treated sugar beet waste and Glomus mosseae inoculation in $\mathrm{Zn}$ contaminated soil. Applied Soil Ecology 33:87-98.

Pérez de Mora, A., P. Burgos, E. Madejón, F. Cabrera, P. Jaeckel, and M. Schloter. 2006. Microbial community structure and function in a soil contaminated by heavy metals: effects of plant growth and different amendments. Soil Biology and Biochememistry 38:327-341.

Smith, E., R. Naidu, and A. M. Alston. 1998. Arsenic in the environment: a review. Advances in Agronomy 64:149-195.

Smith, S. E., D. J. Read, and J. L. Harley. 1997. Mycorrhizal symbiosis. Academic Press, London.

Tordoff, G. M., A. J. M. Baker, and A. J. Willis. 2000. Current approaches to the revegetation and reclamation of metalliferous mine wastes. Chemosphere 41:219-228.

Treseder, K. K., and M. F. Allen. 2000. Mycorrhizal fungi have a potential role in soil carbon storage under elevated $\mathrm{CO}_{2}$ and nitrogen deposition. New Phytologist 147:189-200.

Trevors, J. T. 1984. Dehydrogenase activity in soil: a comparison between the INT and the TTC assay. Soil Biology and Biochemistry 1:673-674.

Ure, A. M., P. H. Quevauviller, H. Muntau, and B. Griepink. 1993. Speciation of heavy metals in soils and sediments. An account of the improvement and harmonisation of extraction techniques undertaken under the auspices of the BCR of the Commission of the European Communities. International Journal of Environmental Analytical Chemistry 51:135-151.

Vivas, A., J. M. Barea, and R. Azcón. 2005. Brevibacillus brevis isolated from cadmium- or zinc-contaminated soils improves in vitro spore germination and growth of Glomus mosseae under high $\mathrm{Cd}$ or $\mathrm{Zn}$ concentrations. Microbial Ecology 3:416-424.

Weissenhorn, I., C. Leyval, and J. Berthelin. 1995. Bioavailability of heavy metals and abundance of arbuscular mycorrhiza in a soil polluted by atmosphere deposition from a smelter. Biology and Fertility of Soils 19:22-28. 